\title{
Commentary Why aren't we practising homogenized medicine?
} Mervyn Singer

\begin{abstract}
Bloomsbury institute of Intensive Care Medicine, Wolfson Institute for Biomedical Research and Department of Medicine, University College London, Gower Street, London WC1E 6BT, UK
\end{abstract}

Corresponding author: Mervyn Singer, m.singer@ucl.ac.uk

Published: 21 August 2007

This article is online at http://ccforum.com/content/11/4/157

(c) 2007 BioMed Central Ltd

Critical Care 2007, 11:157 (doi:10.1186/cc6086)

See related research by Mclntyre et al., http://ccforum.com/content/11/4/R74

\begin{abstract}
Why is the practice of intensive care so heterogenous? Uncertainty as to 'best practice', conservatism, and complacency may all contribute to our divergent management strategies. The need for further generalisable research, anonymised audit, external peer review and open access databases is discussed.
\end{abstract}

Lauralyn Mclntyre and colleagues [1] have neatly used a septic shock scenario-based survey to highlight considerable variations within Canadian critical care practice. They acknowledge the potential pitfalls of translating survey results into 'real life'; however, my own experience of the diversities within UK practice suggest this would be representative of at least one other industrialized country, albeit with some variation in the detail (for example, use of gelatin as a plasma expander is much commoner in Europe).

They found decisions regarding treatment strategy (choice of fluid, use of inotropes and transfusion triggers) to be highly variable. However, they did demonstrate consistency in a continuing reliance on 'basic' monitoring (blood pressure, heart rate, central venous pressure, urine output, pulse oximetry). This was to the relative exclusion of other, more sophisticated techniques (cardiac output, central venous saturation) whose use has been linked with outcome improvements in specific situations, such as the scenario on which their survey was based.

Is this heterogeneity a triumph of uncertainty and/or natural conservatism and/or arrogance and/or sloth over heavily promoted, multiple Society-endorsed guidelines [2] based primarily on the important yet limited Rivers study [3]? Why aren't we all practising homogenized medicine? What does it take to standardize our approach to care of the critically ill?

Uncertainty does exert a considerable effect. The Institute of Healthcare Improvement's Surviving Sepsis Campaign web- site [4] boldly states that a bundle - a group of interventions related to a disease process - "when executed together will result in better outcomes than when implemented individually" and that "the science behind the elements of a bundle is so well-established (my italics) that their implementation should be considered a generally accepted practice." Yet three of the major planks upon which the two sepsis bundles are based, namely the use of corticosteroids, activated protein $\mathrm{C}$ and early goal-directed therapy are currently being questioned via, respectively, the CORTICUS study findings, the European Agency for the Evaluation of Medicinal Products (EMEA), and the National Institutes of Health (through their recent \$8.4M funding of the ProCESS study). These new challenges will, I believe, serve to increase uncertainty still further in the short-term and, thus, affect participation in an approach that is worthy but, in my opinion, critically flawed through a lack of prospective validation [5].

Medics are a naturally conservative bunch - the avid uptake of new technologies by a rapid responder minority is rarely translated into standard practice, often because the initial enthusiasm for a drug, device or strategy fails to pass muster when more rigorously scrutinised or trialled. Too many bandwagons have lost their wheels and this has nurtured an understandable cynicism. It was not that many years ago that we were being exhorted to use high doses of dobutamine to achieve 'supranormal' cardiorespiratory goals in the critically ill, as an extrapolation of findings from a high-risk surgical patient cohort [6]. When subsequent randomised trials made it painfully clear that the intensive care unit (ICU) patient outcomes did not match up to expectation $[7,8]$, the concept was generally discarded, even from the surgical patient population in whom the benefit was repeatedly seen $[9,10]$.

What about complacency? I've yet to meet a self-confessed mediocre intensivist so we all need to take a critical and

$\mathrm{ICU}=$ intensive care unit. 
regular look at our own individual performance. We do require a healthy degree of self-confidence to support our decision-making ability, but are we ready to accept that our ICU is perhaps offering an inferior level of care to the hospital down the road? Or if we do acknowledge poor performance, is this from someone/everyone/anyone else but me? Anonymised audit should, in a non-threatening manner, facilitate recognition and, hopefully, correction of our shortcomings. The Dutch offer external peer review 'visitations' that can be initiated either by the ICU or their hospital administration. How widespread is this practice?

Finally, it is also a deficiency of ourselves as a community that we still cannot answer many fundamental questions. For an individual patient, what constitutes optimal targets, for example, for blood pressure and tissue perfusion, or 'best' treatment, such as the optimal duration of a course of antibiotics? Altruistic, multi-centre, generalisable research addressing simple questions is evolving. The Canadians and Australasians have clearly led the way while European and other countries are catching up. Perhaps these studies could (should) be better coordinated to complement each other. Perhaps this spirit of cooperation could (should) also be extended to open access, anonymised patient databases as a means of comparing models of care and for future hypothesis generation.

\section{Competing interests}

The author declares that they have no competing interests.

\section{References}

1. Mclntyre LA, He'bert PC, Fergusson D, Cook DJ, Aziz A, for the Canadian Critical Care Trials Group: A survey of Canadian intensivists' resuscitation practices in early septic shock. Crit Care 2007, 11:R74

2. Dellinger RP, Carlet JM, Masur H, Gerlach H, Calandra T, Cohen J, Gea-Banacloche J, Keh D, Marshall JC, Parker MM, et al. for the Surviving Sepsis Campaign Management Guidelines Committee: Surviving Sepsis Campaign Guidelines for management of severe sepsis and septic shock. Crit Care Med 2004, 32:858-873.

3. Rivers E, Nguyen B, Havstad S, Ressler J, Muzzin A, Knoblich B, Peterson E, Tomlanovich M; Early Goal-Directed Therapy Collaborative Group: Early goal-directed therapy in the treatment of severe sepsis and septic shock. N Engl J Med 2001, 345:1368-1377.

4. Institute for Healthcare Improvement: Surviving Sepsis Campaign [http://www.ihi.org/lHI/Topics/CriticalCare/Sepsis/Changes/]

5. Singer M: The Surviving Sepsis guidelines: evidence-based ... or evidence-biased? Crit Care Resusc 2006, 8:244-245.

6. Shoemaker WC, Appel PL, Kram HB, Waxman K, Lee TS: Prospective trial of supranormal values of survivors as therapeutic goals in high-risk surgical patients. Chest 1988, 94: 1176-1186.

7. Gattinoni L, Brazzi L, Pelosi P, Latini R, Tognoni G, Pesenti A Fumagalli R: A trial of goal-oriented hemodynamic therapy in critically ill patients. N Engl J Med 1995, 333:1025-1032.

8. Hayes MA, Timmins AC, Yau EH, Palazzo M, Hinds CJ, Watson $D$ : Elevation of systemic oxygen delivery in the treatment of critically ill patients. N Engl J Med 1994, 330:1717-1722.

9. Boyd O, Grounds RM, Bennett ED: A randomized clinical trial of the effect of deliberate perioperative increase of oxygen delivery on mortality in high-risk surgical patients. JAMA 1993, 270:2699-2707.

10. Wilson J, Woods I, Fawcett J, Whall R, Dibb W, Morris C, McManus E: Reducing the risk of major elective surgery: randomised controlled trial of preoperative optimisation of oxygen delivery. BMJ 1999, 318:1099-1103. 